\title{
MISTAKE AS TO IDENTITY AGAIN
}

The last half century has seen an unconscionable accumulation of case law and academic comment on the subject of mistake as to identity in the law of contract. Much of it has been conflicting. The recent decision of the English Court of Appeal in Lewis v. Averay represents a welcome attempt to clear a way through this accumulation and to restore the less complicated principles enunciated in Phillips v. Brooks $L t d .{ }^{2}$ and the cases which preceded it. A contract lawyer's only regret must be that, the common law system being what it is, the clearingaway has had to be less than total.

The facts were in familiar form. A young man had advertised his car for sale at 450 pounds. A man called to buy it, passing himself off as Richard Green, the film actor. He offered to pay by cheque and asked to take the car with him. At this point he was asked for some proof of identity and produced a stamped pass of admission to Pinewood Studios. This bore the name "Richard A. Green" together with an address and a photograph of the buyer. This satisfied the seller, who handed over the car. The buyer turned out to be a rogue, who sold the car to an innocent third party. The cheque, of course, was not met. The seller sued the third party for conversion and was awarded 330 pounds damages in the County Court. From this decision the third party appealed. All three members of the Court of Appeal agreed that the appeal should be allowed, but for different reasons.

Predictably, Lord Denning M.R. was the most direct in his approach. He saw Pothier's views on mistake as forming no part of English law and Sowler v. Potter ${ }^{3}$ as having, therefore, been wrongly decided. He thought that the facts of Phillips v. Brooks ${ }^{4}$ and Ingram v. Little $^{5}$ were indistinguishable and that the decisions were irreconcilable. Of the two cases, he clearly preferred the former. $\mathrm{He}$ rejected, as a distinction between the two, the suggestion (originally made by Viscount Haldane in Lake v. Simmons ${ }^{6}$ ) that in Phillips v. Brooks ${ }^{7}$ the contract had been concluded before the misrepresentation as to identity had been made. Equally, he rejected any supposed distinctions between mistake as to identity and mistake as to attributes. He saw such distinctions as unreal and as doing no good to the law. In his view, it was wrong that an innocent third party should be made to pay for the seller's mistakes. The true principle, he thought, was that when two parties have come to what appears to be a contract, mistake as to identity makes it voidable, not void.

At this stage, though, Lord Denning had to take account of Ingram v. Little. ${ }^{8}$ He seized upon the presumption, postulated in that case by Devlin and Pearce L.JJ., that a person intends to contract with the one to whom his words are physically addressed.9 Lord Denning characterized this as an irrebuttable presumption of law, which seems to follow

1 [1971] 3 All E.R. 907.

2 [1919] 2 K.B. 243.

3 [1940] 1 K.B. 271 .

- Supra, n. 2.

s [1961] 1 Q.B. 31 (C.A.).

6 [1927] A.C. 487 at 501.

7 Supra, n. 2.

B Supra, n. 5.

Id. at 57,66 . 
from his approval of United States authority to the effect that "The Courts hold that if $A$ appeared in person before $B$, impersonating $C$, an innocent purchaser from $A$ gets the property in the goods against B."10

Phillimore L.J., in a brief judgment, relied on the same presumption, but in the form in which it had originally been stated by Pearce L.J., namely, as a prima facie presumption only. Confining Ingram v. Little ${ }^{11}$ to its own peculiar facts, he held that there was nothing in the facts of the present case to rebut that presumption or to distinguish the case from Phillips v. Brooks. ${ }^{12}$

For his part, Megaw L.J. deprecated the test, adopted by the majority in Ingram v. Little, ${ }^{13}$ which asked how the promisee ought to have interpreted the offeror's promise. This he saw as making the existence of the contract depend on the state of mind of a rogue. He went on to adopt a test propounded in Cheshire and Fifoot in the Law of Contract. ${ }^{14}$ This was that, at the time the seller made his offer, he regarded the identity of the offeree as a matter of "vital importance". On this test, the present seller must fail since the evidence was that his concern was with creditworthiness rather than with identity.

Lewis v. Averay ${ }^{15}$ appears to have advanced the law to the following state: Where parties are face to face, there is a presumption that the mistaken party is contracting with the other of them. This presumption is (pace Lord Denning) rebuttable. In particular, it will be rebutted if the rogue represents himself as an agent of a third party ${ }^{16}$ or possibly if the mistaken party can show that, when he made his offer, identity was of "vital importance" to him. In this latter context, distinctions between identity and attributes may still arise.

It has always seemed to the present commentator unreal in the extreme to ask, in whatever form, whether a seller contracted with, or intended to deal with, on the one hand the person present before him or, on the other, the person whom he represented himself to be. Both the offer and acceptance test and the "identity and attributes" test tend to ask that question. But it is a question which raises false alternatives, so that the answers given have had to be artificially constructed. In truth, the seller deals with the person before him, believing him to be someone else. If Lewis v. Averay ${ }^{17}$ has eliminated this particular false dilemma, it will have achieved something worthwhile. It seems a pity, though, that the topic should still be encumbered with the notion of a presumption, whether rebuttable or not. The substance of the decision could have been achieved much more simply and directly by a return to the reasoning of Horridge J. in Phillips v. Brooks. ${ }^{18}$ At an early stage in his judgment, that learned judge adopted as stating his own view of the law the following propositions from the headnote

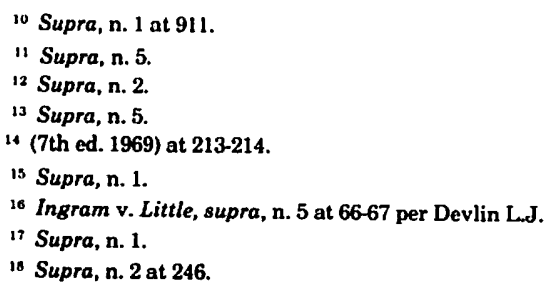


to an American case, Edmunds v. Merchants' Dispatch Transportation Co: ${ }^{19}$

(1) If A., fraudulently assuming the name of a reputable merchant in a certain town, buys, in person, goods of another, the property in the goods passes to $\mathrm{A}$.

(2) If A., representing himself to be a brother of a reputable merchant in a certain town, buying for him, buys, in person, goods of another, the property in the goods does not pass to $\mathrm{A}$.

The first proposition is in effect an expression of Lord Denning's own principle, at least in the inter praesentes situation. It means that when parties are face to face, the fact that one may be mistaken as to the identity of the other will not prevent the formation of a valid, albeit voidable, contract. Conceptually, at least, the second proposition involves no contradiction or exception to that rule. When a contract made by a purported agent fails, it is not because of the mistake but because of a want of authority to bind the alleged principal. Between them, these two propositions cover virtually every reported case of mistake as to identity between parties face to face. Coverage can be extended even further if a small amendment is made to proposition (1). In Ingram v. Little, ${ }^{20}$ as has already been mentioned, Devlin and Pearce L.JJ. referred to a presumption that a person intends to contract with the one to whom his words are "physically addressed". If the first proposition is rephrased so that a mistaken party is seen to be bound by the apparent contract with the person to whom his communications are "physically addressed", the two rules between them cover not only almost all the face-to-face cases but also those where the parties were communicating by correspondence. Thus, the first proposition explains not only Phillips v. Brooks ${ }^{21}$ but also Cundy v. Lindsay, ${ }^{22}$ King's Norton Metal Co. v. Eldridge, Merrett \& Co., ${ }^{23}$ Fawcett v. Star Car Sales ${ }^{24}$ and even Boulton v. Jones. ${ }^{25}$ The second proposition sufficiently accounts for Hardman v. Booth ${ }^{26}$ and Lake v. Simmons. ${ }^{27}$ Dennant v. Skinner ${ }^{28}$ falls outside it and within the first proposition because the representation of agency in that case was not made until after the car had already been knocked down to the cheat at auction.

It is true that this still leaves to be accounted for, cases like Sowler v. Potter, ${ }^{29}$ Gordon v. Street ${ }^{30}$ and Ingram v. Little ${ }^{31}$ itself. Assuming these do have to be accounted for, as distinct from being dismissed as wrongly decided, it is quite possible to do so without creating any exception to the first two propositions. The way to do so is by using an idea which can be traced from the judgment of Bramwell $B$. in

\footnotetext{
19 (1883) 135 Mass. 283 at 284.

${ }^{20}$ Supra, n. 5 at 57, 66.

21 Supra, n. 2.

22 (1878) 3 App. Cas. 459.

23 (1897) 14 T.L.R. 98.

24 [1960] N.Z.L.R. 406.

25 (1857) 27 L.J. Ex. 117.

28 (1863) 1 H. \& C. 803.

${ }^{27}$ Supra, n. 6.

2" [1948] 2 K.B. 164.

${ }^{29}$ Supra, n. 3.

${ }^{30}$ [1899] 2 Q.B. 641.

31 Supra, n. 5.
} 
Boulton v. Jones, ${ }^{32}$ through the explanation for Sowler v. Potter ${ }^{33}$ by A. L. Goodhart in his well-known article on "Mistake as to Identity in the Law of Contract" 34 and the judgment of Devlin L.J. in Ingram v. Little $^{35}$ to the judgment of Megaw L.J. in Lewis v. Averay. ${ }^{36}$ It is contained, also, in the famous summary of the law of mistake made by Denning L.J. in Solle v. Butcher. ${ }^{37}$ Though it has taken different conceptual forms, the idea conveyed has been that mistake as to identity will avoid the contract if the identity of the other party has been a basic condition of the mistaken party's willingness to contract with him in the first place. Conceptually, that idea is most neatly expressed by saying that the mistaken party has made the identity of the other a condition precedent to the existence of any contract between them. The presence or absence of such a condition in any particular case would depend in large measure on how "important", "vital" or "fundamental" a court might see the question of identity in relation to the apparent contract in the light of the circumstances in which the negotiations occurred. One would not expect such a condition to occur very frequently. More often than not, identity, where it was important, would be a matter of promise rather than of condition precedent.

It is submitted, therefore, that there is nothing in the cases to prevent adoption of the view that mistake as to identity per se will never prevent a contract arising with the person to whom the mistaken party physically addresses himself. When an apparent contract fails, it will be because one party warranted an agency which did not exist, or because the question of identity was made a condition of the very existence of the contract in the first place. That is not so very different from the conclusion reached by Slade ("The Myth of Mistake") 38 nearly twenty years ago.

Of course, it has to be conceded that this conclusion, however much it may simplify the law and reduce the potential incidence of void contracts, does nothing to solve what many would regard as the real problem. Why, it might be asked, should the rights of an innocent third party have to turn on whether a rogue said "I am X" rather than "I represent X"? But such is the way the common law works at times. As Devlin L.J. indicated in Ingram v. Little, ${ }^{39}$ only the legislature can now enable the courts to strike a proper balance amongst all those affected by mistake.

\footnotetext{
32 Supra, n. 25 at 119.

33 Supra, n. 3.

34 (1941) 57 L.Q.R. 228.

${ }^{35}$ Supra, $\mathrm{n} .5$ at 67 et seq.

36 Supra, n. 1.

3: [1950] I K.B. 671 at 691 .

3s (1954) 70 L.Q.R. 385.

39 Supra, n. 5 at 73-74.

- Professor of Law, University of Auckland.
} 